\title{
Spørgetid
}

\section{EU-traktat og folkeafstemning?}

Spm. nr. US 137

Martin Henriksen (DF):

Det, jeg godt kunne tænke mig at spørge ind til, er det uformelle møde om EU-forfatningen, som blev holdt mellem den nyvalgte franske præsident Sarkozy og det tyske formandskab ved Angela Merkel. Jeg kunne godt tænke mig at høre, om regeringen ved, hvad der kom ud af det uformelle møde i forbindelse med udarbejdelse af forfatningstraktaten. I den anledning kunne jeg også spørge, nu, hvor jeg forstår, at statsministeren har været nede hos det tyske formandskab, om man der har drøftet det videre forløb for EU-forfatningen, og hvad man eventuelt er nået frem til i de drøftelser.

\section{Udenrigsministeren (Per Stig M $\varnothing$ ller):}

Jeg har ikke nogen specielle meldinger om Sarkozy-Merkel-mødet, så det vil jeg ikke være i stand til at oplyse Folketinget om. Hr. Anders Fogh Rasmussen har ikke været hos Merkel, han er hos Merkel i dag, og derfor kan jeg jo heller ikke oplyse, hvad der er kommet ud af mødet, når mødet finder sted eller skal til at finde sted eller måske lige har fun- det sted. I hvert fald er det i dag, mødet finder sted.? Sarkozys position kan hr. Martin Henriksen orientere sig om i aviserne, men den danske position er, at vi synes, at forfatningstraktaten er en god traktat. Hvis man kan få den igennem, synes vi, det er fint, men kan man ikke få den igennem, ønsker vi at få de væsentligste fornyelser bragt ind ?i en mindre traktat.

\section{Martin Henriksen:}

Så kunne man jo så problematisere det, at EU-forfatningen reelt er blevet forkastet ved to folkeafstemninger. Det ved jeg godt måske er en længere diskussion at gå ind i, og som vi ikke har tid til her. Men ministeren var sådan set lidt inde på det, og vi spurgte også ind til det i sidste uge, tror jeg, det var, da vi havde en debat på baggrund af et beslutningsforslag fra Dansk Folkeparti. Jeg kunne godt tænke mig at høre, hvad regeringen og statsministeren konkret siger til det tyske formandskab, altså hvilke overvejelser man har omkring EU-forfatningen. Kan ministeren ikke pege nogle ting ud, som man synes er mere væsentlige end andre, som man ønsker at 
lægge vægt på i forhandlingerne om den her nye EU-forfatning? Jeg synes, det er relevant, og jeg synes også, at Folketinget og folk, der sidder og lytter, har krav på at vide det.

\section{Udenrigsministeren (Per Stig Møller):}

Det synes jeg da i høj grad er relevant. Jeg synes, det er et godt spørgsmål. Der er bare det ved det, at det jo er blevet besvaret utallige gange. Vi har haft en folketingsdebat om det, som hr. Martin Henriksen rigtigt siger. Vi har også en vedtagelse i Folketinget, hvori Folketinget præciserer, hvad den danske position er i forbindelse med forhandlingerne. Så der er såmænd ikke noget nyt, men jeg skal gerne rekapitulere. Som jeg sagde før: Vi synes, forfatningstraktaten er en god traktat. Hvis den kan komme igennem, er det godt for os, men kan den ikke komme igennem, fordi, som hr. Martin Henriksen siger, at to lande har stemt nej, og de fastholder deres nej til forfatningstraktaten, som den er, må vi jo finde en anden løsning. Der er nogle ting, som er en fordel: Der er det, at vi får en fast formand for Rådet, som skulle betyde, at vi kommer til at arbejde bedre og mere effektivt, der er det, at EU får en fast udenrigsrepræsentant, og at man søger at få mere enstemmighed omkring udenrigspolitikken, uden at det er et must, et krav, men man forsøger at gøre det. Stemmevægtene ændres, så de bliver mere retfærdige for nogle af de nye lande, den slags ting er jo nødvendige. Og så kommer der flere flertalsafgørelser. Hvis det står til os, og vi skal have en mindre traktat, skal der også være flere flertalsafgørelser. Det betyder så også, at vi kan få effektiviseret arbejdet, og samtidig betyder det, at Europa-Parlamentet får en større indflydelse, for hvor der er flertalsafgørelser, skal Europa-Parlamentet også ind. Derved demokratiserer vi arbejdet mere. Så nogle af de ting, vi lægger vægt på, bliver revet over, hvis forfatningstraktaten ikke kan vedtages, som den er.

\section{Martin Henriksen:}

Netop i forlængelse af, at regeringen gerne ser flere flertalsafgørelser, er der jo nogle, der tolker det som værende suverænitetsafgivende. $\mathrm{Nu}$ ved jeg godt, at regeringen ikke gør det, men det er der i hvert fald nogle, der gør, bl.a. Dansk Folkeparti. I forbindelse med den udmelding, som kom i pressen fra SF og fra Dansk Folkeparti, som gik ud og sagde, at de to partier mener, at der skal være en folkeafstemning om den nye traktat, kunne jeg godt tænke mig at stille et spørgsmål. Jeg kender jo regeringens hidtidige position, som er, at man ikke vil tage stilling til det på nuværende tidspunkt, men i forlængelse af, at der netop er kommet det her - så vidt jeg husker, er det også noget nyt, at SF går ud og siger på linje med Dansk Folkeparti og Enhedslisten, at der er behov for en folkeafstem- 
ning, når man har haft de her drøftelser om indholdet $\mathrm{i}$ traktaten - har regeringen så genovervejet sin holdning til en folkeafstemning, og går regeringen nu ind for en folkeafstemning? Det er trods alt relevant, at danskerne får mulighed for at sige ja eller nej til det grundlag, som det europæiske samarbejde fremover skal baseres på.

\section{Udenrigsministeren (Per Stig Møller):} Det er jo også et spørgsmål, vi har haft mange gange. Jeg tror, hr. Morten Messerschmidt også har prøvet en hel del gange her fra pladsen. Det er egentlig ikke sket før, at man har taget stilling til en folkeafstemning, før man kendte traktaten, så SF og Dansk Folkeparti - jeg tror også, Enhedslisten er enig i det, men i hvert fald de to partier - beder om, at vi leverer en vare, vi ikke tidligere har leveret. Der har ikke ved de tidligere traktater på det her tidlige stadium i forhandlingsprocessen været nogen regering, som har sagt, at det skal vi have en folkeafstemning om. Det vil jeg heller ikke gøre. Det må afhænge af, hvad det er for en traktat, og så må vi jo se på traktaten i forhold til behovet for en folkeafstemning.

\section{Formanden:}

Så er det hr. Martin Henriksen for et afsluttende spørgsmål.

\section{Martin Henriksen:}

Men netop i forlængelse af, at rege- ringen og, sådan som jeg har forstået det, mange andre medlemslande ønsker flere flertalsafgørelser, og netop i respekt for, at der bl.a. er nogle, der opfatter det som værende suverænitetsafgivende, kan man vel godt fristes til at tro, at det så rent faktisk også kommer igennem. Derfor ville det jo være rimeligt nok, at man sagde, at vi skulle have en folkeafstemning også på nuværende tidspunkt. Når nu ministeren og regeringen og de andre EU-positive partier taler om, at vi skal demokratisere EU, er det vel også meget rimeligt, hvis man så sagde, at vi har et princip om, at når der kommer et nyt traktatgrundlag, som vi skal tage stilling til, er det også et sundt princip, at det selvfølgelig så bliver lagt ud til folkeafstemning. Kan ministeren ikke se en vis logik i det, også når ministeren skal leve op til sine egne ord om, at vi skal have demokratiseret EU? Det synes jeg sådan set kan være meget fornuftigt. Så skal vi ikke have en folkeafstemning i forlængelse af ministerens fornuftige principper?

\section{Udenrigsministeren (Per Stig Møller):} Jeg er glad for, at hr. Martin Henriksen synes, mine principper er fornuftige. Et af principperne er det, at man ikke tager stilling til en sag, før man kender sagens indhold. Ved Nicetraktaten havde man fx ikke nogen folkeafstemning. Så jeg vil sige, at vi må vente med afgørelsen, til vi ved, hvad det er for en traktat, lige- 
som alle tidligere regeringer har gjort. Med hensyn til flertalsafgørelse er det rigtigt, at der kan der være suverænitetsafgivelse, og så giver det jo sig selv. Der skal være en folkeafstemning, hvis der er suverænitetsafgivelse. Men man kan godt have flertalsafgørelser, uden at der er en ny suverænitetsafgivelse. Det kan man inden for områder, hvor man har afgivet suverænitet. Så må vi jo også igen se på: Er det inden for områder, der er afgivet suverænitet på, el- ler er det nye områder, der kommer ind? Det kan vi jo også først vide, når vi er færdige med forhandlingerne. Så skal vi nok også tage en diskussion om det. Jeg er sikker på, at vi tager mange her i salen, og vi tager også mange sammen. Lad os glæde os til de diskussioner til den tid, når vi har et bedre grundlag at diskutere på.

Folketinget, 22. maj 2007 